\title{
Neonatal Diabetes Mellitus
}

\author{
Jacques Beltrand ${ }^{1,2,3+}$, Kanetee Busiah ${ }^{1,4+}$, Laurence Vaivre-Douret ${ }^{1,2,5}$, \\ Anne Laure Fauret ${ }^{6}$, Marianne Berdugo ${ }^{2,7}$, Hélène Cavé ${ }^{2,6}$ and Michel Polak ${ }^{1,2,3 *}$ \\ ${ }^{1}$ Paediatric Endocrinology, Gynaecology and Diabetology, Necker-Enfants Malades University Hospital, Assistance \\ Publique-Hôpitaux de Paris, IMAGINE Institute, ENDO-European Reference Network Team, Paris, France, ${ }^{2}$ Faculty of \\ Medicine, Université de Paris, Paris, France, ${ }^{3}$ INSERM U1016, Cochin Institute, Paris, France, ${ }^{4}$ Paediatric Endocrinology, \\ Diabetology and Obesity Unit, Lausanne University Hospital, University of Lausanne, Lausanne, Switzerland, ${ }^{5}$ Inserm \\ UMR-1018-CESP, Necker-Enfants Malades University Hospital Paedopsychiatry Department, Cochin University Hospital \\ Paediatrics Department, Institut Universitaire de France, Assistance Publique-Hôpitaux de Paris, Université de Paris, Paris, \\ France, ${ }^{6}$ Genetics Department, Robert-Debré University Hospital, Assistance Publique-Hôpitaux de Paris, Paris, France, \\ ${ }^{7}$ INSERM U1138, Cordeliers Research Centre, Paris, France
}

\section{OPEN ACCESS}

Edited by:

Amanda Lesley Ogilvy-Stuart, Cambridge University Hospitals NHS

Foundation Trust, United Kingdom

Reviewed by: Jean-Pierre Chanoine, University of British Columbia, Canada Timo Otonkoski, University of Helsinki, Finland

*Correspondence: Michel Polak michel.polak@aphp.fr

tThese authors share first authorship

Specialty section

This article was submitted to Pediatric Endocrinology, a section of the journal Frontiers in Pediatrics

Received: 05 March 2020

Accepted: 13 August 2020 Published: 30 September 2020

Citation:

Beltrand J, Busiah K, Vaivre-Douret L,

Fauret $A L$, Berdugo $M$, Cavé $H$ and Polak M (2020) Neonatal Diabetes Mellitus. Front. Pediatr. 8:540718 doi: 10.3389/fped.2020.540718
Neonatal Diabetes (ND) mellitus is a rare genetic disease (1 in 90,000 live births). It is defined by the presence of severe hyperglycaemia associated with insufficient or no circulating insulin, occurring mainly before 6 months of age and rarely between 6 months and 1 year. Such hyperglycaemia requires either transient treatment with insulin in about half of cases, or permanent insulin treatment. The disease is explained by two major groups of mechanism: malformation of the pancreas with altered insulin-secreting cells development/survival or abnormal function of the existing pancreatic $\beta$ cell. The most frequent genetic causes of neonatal diabetes mellitus with abnormal $\beta$ cell function are abnormalities of the 6q24 locus and mutations of the ABCC8 or KCNJ11 genes coding for the potassium channel in the pancreatic $\beta$ cell. Other genes are associated with pancreas malformation or insufficient $\beta$ cells development or destruction of $\beta$ cells. Clinically, compared to patients with an ABCC8 or KCNJ11 mutation, patients with a 6q24 abnormality have lower birth weight and height, are younger at diagnosis and remission, and have a higher malformation frequency. Patients with an ABCC8 or KCNJ11 mutation have neurological and neuropsychological disorders in all those tested carefully. Up to $86 \%$ of patients who go into remission have recurrent diabetes when they reach puberty, with no difference due to the genetic origin. All these results reinforce the importance of prolonged follow-up by a multidisciplinary pediatric team, and later doctors specializing in adult medicine. $90 \%$ of the patients with an ABCC8 or KCNJ11 mutation as well as those with $6 q 24$ anomalies are amenable to a successful switch from insulin injection to oral sulfonylureas.

Keywords: neonatal diabetes mellitus, chromosome 6q24 abnormality, associated malformations, neuropsychological disorder, KCNJ11 (Kir6.2), ABCC8, sulfonylurea receptor (SUR1) 


\section{DEFINITION}

Diabetes mellitus in very young children or neonatal diabetes is a rare genetic disease (minimal incidence: 1 in 90,000 live births) with variations within different ethnic groups (1-3). It is defined by the presence of severe hyperglycaemia requiring treatment and occurs between the neonatal period and infancy. It occurs mainly before 6 months of age (155/173 probands in our published cohort) and rarely between 6 months and 1 year (18/173) (4). In the Finnish population for example, after 6 months of age, patients with diabetes had high HLA risk genotypes and islet autoantibodies, reflecting the autoimmune character of diabetes (5). This hyperglycaemia is associated with insufficient or no circulating insulin (3). Two clinical forms have been distinguished, based on the duration of the treatment: a so called "transient form" and a permanent form.

The disease is explained by two major groups of mechanism: malformation of the pancreas or abnormal function of the pancreatic $\beta$ cell that secretes insulin (by poor insulin cell mass development or malfunction of a cell component or by destruction of the $\beta$ cell) (Table 1) (see Figure 1 for the normal functioning of the $\beta$ cell).

\section{GENETIC CAUSES}

\section{Abnormal $\beta$ Cell Function}

The most frequent genetic causes of neonatal diabetes with normal pancreas morphology are abnormalities of the $6 \mathrm{q} 24$ locus and mutations of the genes coding for the ATP-dependent potassium channel.

\section{6q24 (MIM\#601410 and 603044)}

The first genetic causes identified were abnormalities of the 6q24 locus, which include paternal uniparental disomy of 6q24 (pUPD6), partial duplication of paternal 6q24 and relaxation of the maternal 6q24 imprinted locus. This locus contains a CpG island, presenting differential methylation depending on the parental origin (non-methylation on the paternal allele, methylation on the maternal allele) (6). To date, the methylation abnormality has not been found in the parents of affected children. Methylation is used to down-regulate gene transcription of the methylated allele. All these abnormalities lead to over-expression of imprinted genes located in 6q24, such as PLAGL1/ZAC (pleiomorphic adenoma gene-like 1) and HYMAI (Hydatidiform mole-associated and imprinted transcript), which are the most "likely" candidate genes (6-8). PLAGL-1 codes for a transcription factor involved in regulation of stopping the cell cycle and apoptosis and in induction of the receptor 1 gene for human pituitary adenylate cyclase-activating polypeptide (PACAP1, which is a potent stimulant of insulin secretion). The function of the HYMAI gene is unknown (9). The mechanism responsible for the diabetes could be linked to a developmental defect in the $\beta$ cells but the fact that remission of the diabetes occurs means that an abnormality in $\beta$ cell function cannot be ruled out (10). The $6 \mathrm{q} 24$ abnormalities are associated with "transient" neonatal diabetes $(7,8,11)$.
The ZFP57 gene (MIM *612192) is involved in maintaining methylation of the DNA during the very early stages of embryogenesis. It is localized at 6 p22.1. Homozygous mutations leading to a lack of protein or non-functional protein are associated with widespread DNA hypomethylation, including hypomethylation of the 6q24 locus (12). However, there are patients who have a $6 \mathrm{q} 24$ methylation abnormality not due to mutations of this gene (12).

\section{Mutations of the ABCC8 and KCNJ11 Genes Coding for the K KTP Channel: (MIM *600509 and *600937)}

The ATP-dependent potassium channel ( $\mathrm{K}_{\mathrm{ATP}}$ channel) plays a central role in stimulating insulin secretion by the pancreatic $\beta$ cell in response to glucose. At low blood sugar levels (e.g., fasting), the $\mathrm{K}_{\mathrm{ATP}}$ channels are open (activated) and their activity maintains a hyperpolarized resting membrane potential (around $-70 \mathrm{mV}$ ). A rise in blood sugar level (e.g., post-prandial) causes increased passage of glucose into the $\beta$ cell. Glucose enters the glycolysis pathway, which increases the intracellular ATP concentration. This causes the $\mathrm{K}_{\text {ATP }}$ channels to close (inhibition), which leads to the intracellular potassium accumulation that causes membrane depolarization. This depolarization activates the voltage-dependent calcium channels, leading to $\mathrm{Ca}^{2+}$ ions entering the $\beta$ cell, then enabling exocytosis of the secretion vesicles and release of insulin into the bloodstream (Figure 1).

The $\mathrm{K}_{\mathrm{ATP}}$ channel is an octamer formed from two types of subunits: the Kir6.2 subunits form the channel selective for the incoming corrective potassium enclosed in SUR1 ion-channel regulator subunits $(13,14)$. They are coded by the KCNJ11 and $A B C C 8$ genes, respectively.

Activating mutations in one of these two genes are responsible for neonatal diabetes with normal pancreas morphology (15-17). They result in the $\mathrm{K}_{\mathrm{ATP}}$ channel remaining permanently open, so that it no longer controls membrane potential in response to glucose and therefore blocks the event cascade that leads to insulin release.

\section{Mutations of the Insulin Gene (INS) (MIM *176730)}

The third cause of neonatal diabetes, by frequency, is mutations of the insulin gene (INS). The majority are heterozygous mutations affecting the structure of preproinsulin; these are transmitted in an autosomal dominant manner $(18,19)$. The abnormal proinsulin undergoes degradation in the endoplasmic reticulum, leading to severe endoplasmic reticulum (ER) stress and $\beta$ cell death. This process has been described in mouse models (20) and in man $(21,22)$. Recent evidence suggests that INS mutations do not necessarily lead to beta-cell death but rather the chronic ER stress interferes with beta-cell growth and development (23).

Some mutations alter expression of the protein. They are transmitted in a recessive manner, in the majority of cases in consanguineous families. These mutations affect the insulin promoter directly of by mutation in factor that enhances its activity $(24,25)$. 
TABLE 1 | Genetic causes of monogenic neonatal diabetes based on physiopathological mechanisms [excluding 6q24 locus abnormalities (MIM *601410, *603044, and *612192)].

\begin{tabular}{|c|c|c|c|c|c|}
\hline Gene/Protein & Function & Locus & Transmission mode & Type of diabetes & $\begin{array}{l}\text { Reference } \\
\text { OMIM numbers }\end{array}$ \\
\hline \multicolumn{6}{|c|}{ BETA CELL FUNCTION ABNORMALITY } \\
\hline KCNJ11/Kir6.2 & $\begin{array}{l}\text { KATP channel/insulin } \\
\text { secretion }\end{array}$ & $11 \mathrm{p} 15.1$ & Dominant & PND/TND/iDEND/DEND & $\underline{\mathrm{MIM}}$ *600937 \\
\hline GCK/Glucokinase & Glucose metabolism & 7p15.3-p15.1 & Recessive/Dominant & $\begin{array}{l}\text { Heterozygous: MODY2 } \\
\text { Homozygous: PND }\end{array}$ & $\underline{\text { MIM *138079 }}$ \\
\hline SLC2A2/GLUT2 & Membrane receptor & $3 q 26.1-q 26.2$ & Recessive & $\begin{array}{l}\text { PND/TND + Fanconi-Bickel } \\
\text { syndrome (glycogenosis) } \\
\text { Proximal tubulopathy }+ \text { small size }+ \\
\text { rickets }+ \text { abnormality of glucose and } \\
\text { galactose metabolism }\end{array}$ & MIM *138160 \\
\hline \multicolumn{6}{|c|}{ ENDOCRINE PANCREAS DEVELOPMENT ABNORMALITY } \\
\hline GATA6/GATA6 & Transcription factor & $18 q 11.1-q 11.2$ & Dominant & $\begin{array}{l}\text { PND by pancreas } \\
\text { agenesis/hypoplasia + congenital } \\
\text { cardiopathy + biliary tract } \\
\text { abnormalities }\end{array}$ & MIM *601656 \\
\hline $\begin{array}{l}\text { GLIS3/Zinc finger protein, } \\
\text { GLIS3 }\end{array}$ & Transcription factor & $9 p 24.2$ & Recessive & $\begin{array}{l}\text { PND }+ \text { congenital hypothyroidism } \pm \\
\text { progressive hepatic fibrosis } \pm \text { cystic } \\
\text { renal dysplasia } \pm \text { congenital } \\
\text { glaucoma }\end{array}$ & MIM *610192 \\
\hline $\mathrm{HNF} 1 \beta / \mathrm{HNF} 1 \beta$ & Transcription factor & $17 q 12$ & Dominant & $\begin{array}{l}\text { MODY5 or TND + pancreatic } \\
\text { hypoplasia + renal cyst }\end{array}$ & MIM *189907 \\
\hline NEUROD1/BETA2 & Transcription factor & $2 q 31.3$ & Recessive/Dominant & $\begin{array}{l}\text { Heterozygous: MODY6 } \\
\text { Homozygous: PND }+ \text { cerebellar } \\
\text { hypoplasia + visual defect }+ \\
\text { perceptive deafness }\end{array}$ & MIM *601724 \\
\hline $\begin{array}{l}\text { PAX6/aniridia type II protein, } \\
\text { Pax6 }\end{array}$ & Transcription factor & $11 \mathrm{p} 13$ & Recessive & $\begin{array}{l}\text { PND + microphthalmia + cerebral } \\
\text { malformation }\end{array}$ & MIM *607108 \\
\hline $\begin{array}{l}\text { PDX1 (or IPF1)/ } \\
\text { Pancreas/duodenum } \\
\text { homeobox protein } 1\end{array}$ & Transcription factor & $13 q 12.1$ & Recessive/Dominant & $\begin{array}{l}\text { Heterozygous: MODY } 4 \\
\text { Homozygous nonsense mutation: } \\
\text { PND by agenesis/hypoplasia of the } \\
\text { pancreas } \\
\text { Homozygous hypomorphic mutation: } \\
\text { PND by hypoplasia of the pancreas }\end{array}$ & MIM *600733 \\
\hline $\begin{array}{l}\text { PTF1A/Pancreas } \\
\text { Transcription Factor } 1\end{array}$ & Transcription factor & 10p12.2 & Recessive & $\begin{array}{l}\text { PND by agenesis of the pancreas }+ \\
\text { cerebellar agenesis }\end{array}$ & MIM *607194 \\
\hline RFX6/Rfx6 & Transcription factor & $6 q 22.1$ & Recessive & $\begin{array}{l}\text { Martinez-Frias Syndrome: Pancreatic } \\
\text { hypoplasia + intestinal atresia with } \\
\text { diarrhea + agenesis/hypoplasia of the } \\
\text { gall bladder }\end{array}$ & MIM *612659 \\
\hline CNOT1 & Transcriptional repressor & $16 q 21$ & $\begin{array}{l}\text { De novo specific } \\
\text { mechanism of the mutation }\end{array}$ & $\begin{array}{l}\text { Pancreatic agenesis + } \\
\text { holoprosencephaly }\end{array}$ & MIM *604917 \\
\hline
\end{tabular}


TABLE 1 | Continued

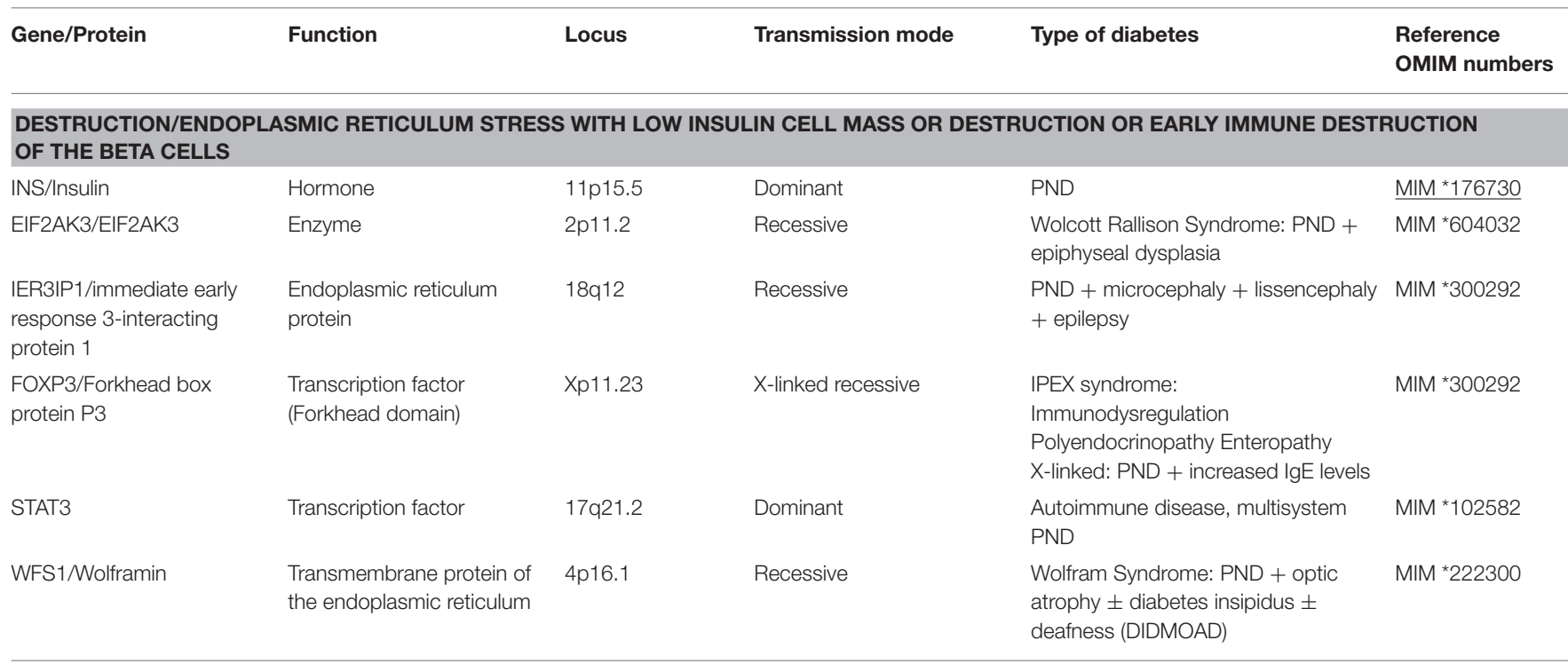

ND, neonatal diabetes; PND, permanent neonatal diabetes; TND, transient neonatal diabetes; DEND, Developmental delay, Epilepsy and Neonatal Diabetes; iDEND, intermediate DEND = DEND without epilepsy; MODY, Maturity Onset Diabetes of the Young.

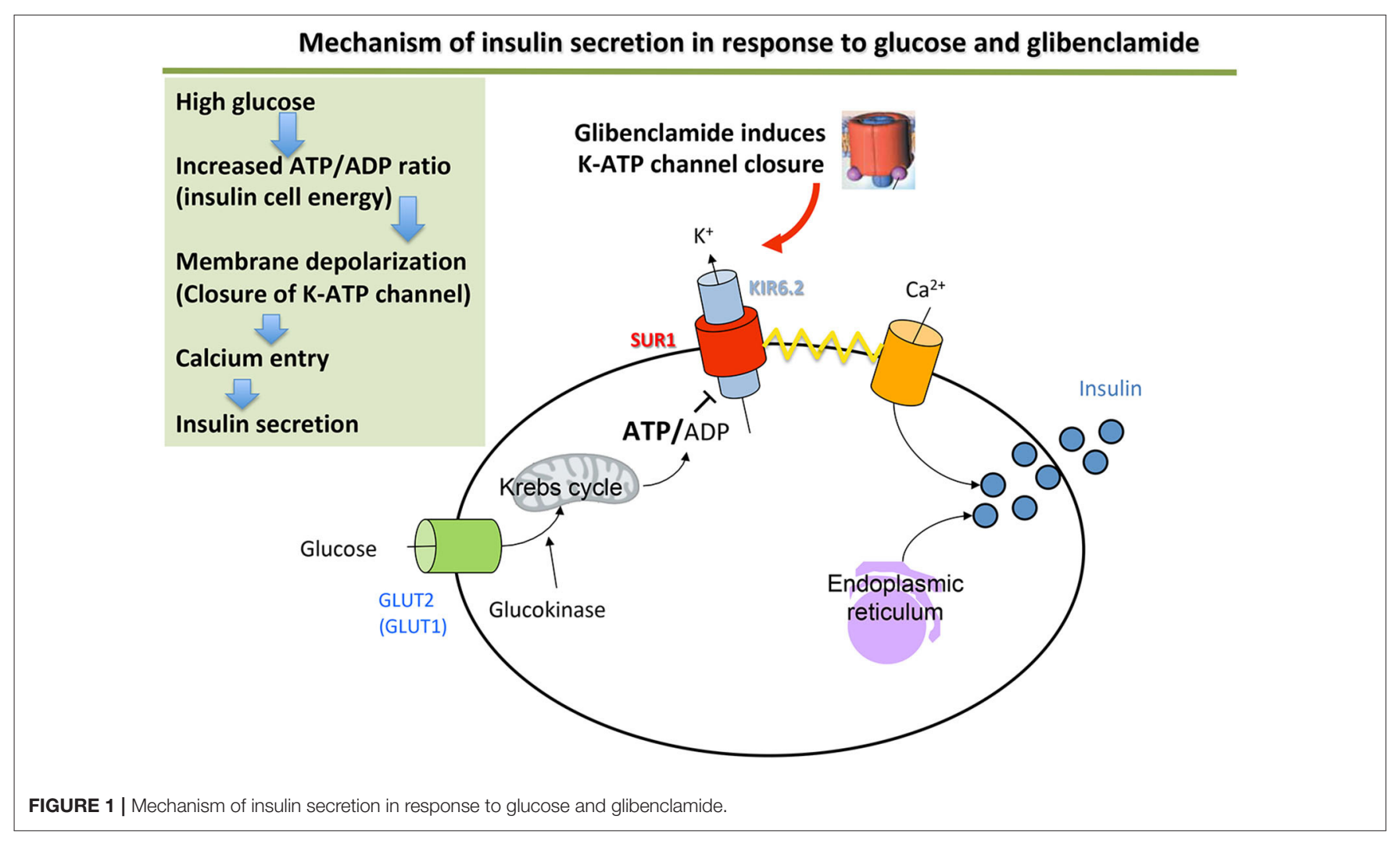

Mutations of the Glucokinase Gene (MIM *138079)

Glucokinase is responsible for the first step of glucose metabolism in the $\beta$ cell. It acts as a "sensor" of blood glucose, making it possible to control the quantity of insulin secreted. Nonsense mutations of the glucokinase gene cause MODY 2 (Maturity onset diabetes in the youth type 2), which usually presents as moderate hyperglycaemia (26). Transmission is heterozygous. In the homozygous state, these nonsense mutations cause neonatal diabetes by complete deficiency of glucokinasemediated glycolysis (27). This is not a frequent cause of neonatal 
diabetes $(28,29)$. However, an assay of the fasting blood glucose concentration is required from both parents, particularly if there is a history of gestational diabetes. The discovery of discreet glucose intolerance in both parents should therefore lead to a search for glucokinase gene mutations.

\section{Abnormal Pancreas Morphology}

Several genes are linked to neonatal diabetes with abnormal pancreas morphology and precise description is beyond the scope of this chapter (see Table 1 for a brief information). These genes are involved in development of the pancreas at various stages in early morphogenesis. These neonatal diabetes cases may be associated with a deficiency of the exocrine pancreas, based on the severity of pancreatic damage or to other congenital malformations. Mutation of the RFX- 6 gene deserves a specific comment. The RFX- 6 transcription factor is involved in the differentiation of beta-cells in the pancreas during embryonic development of the pancreas. It is also expressed in mature cells where it has a role in regulating insulin transcription and secretion. It actually controls the expression and activation of calcium channels and its inactivation alters insulin secretion in response to glucose. A few cases of neonatal diabetes have been reported. Patients display developmental abnormalities of the pancreas and of the digestive tract. The mechanism is linked to both a developmental and a functional disorder of the endocrine pancreas. Transmission is autosomal recessive (Table $\mathbf{1}$ ).

\section{Autoimmune Neonatal Diabetes Mellitus}

Most patients diagnosed with diabetes between 6 and 12 months of age will have the "typical" type 1 diabetes mellitus seen in older children with positive autoantibodies against the beta cell. Autoimmune diabetes is very rare before 6 months of age and will most often be linked to specific causes.

\section{IPEX Syndrome (Table 1)}

Mutations of the FOXP3 gene may be responsible for enteropathy, immune dysregulation and polyendocrinopathy. It is a cause of neonatal diabetes associated with early autoimmunity directed against the beta cells of the pancreas. This diagnosis should be considered in male infants presenting diabetes associated with immune deficiency and/or severe infections. Immunosuppressant treatment can be considered (serolimus, corticosteroids) but bone marrow transplant must be considered as soon as the child's clinical condition allows. Insulin treatment will be combined with specialized nutritional management (parenteral \pm enteral nutrition) before and after the transplant. It should be noted that, while correcting immune deficiencies, this will not eliminate the diabetes.

\section{Down Syndrome and Neonatal Diabetes}

Patients with Down syndrome (DS) resulting from trisomy 21 are more likely to have childhood diabetes mellitus. Professor Hattersley's group found 13 infants affected by DS who were diagnosed with diabetes before the age of 6 months. Trisomy 21 was seven times more likely in their PNDM cohort than in the general population ( 13 of $1,522=85$ of 10,000 observed vs. 12.6 of 10,000 expected). Known PNDM genes explains $82.9 \%$ of nonDS PNDM in their work. None of the 13 DS-PNDM patients had a mutation in those genes. The conclusion from this work is that trisomy 21 is a cause of autoimmune PNDM that is not HLA associated (30).

Other mutations, such as the activating STAT3 mutations have been described which cause neonatal diabetes associated with beta-cell autoimmunity (Table 1).

\section{CLINICAL DESCRIPTION}

There are two clinical forms of neonatal diabetes based on the duration of insulin-dependency. In the transient form, treatment may be stopped at any time from the first weeks of life to 5 years of age (4). In the permanent forms, life-long treatment is necessary.

The clinical difference between transient and permanent neonatal diabetes is not always underpinned by distinct molecular mechanisms. Abnormalities of the 6q24 locus are exclusively linked to transient neonatal diabetes. However, mutations of the $A B C C 8, K C N J 11$, and INS genes are linked to both permanent and transient forms $(17,18,25)$. Other genetic causes are associated with permanent neonatal diabetes.

Neonatal diabetes is usually diagnosed before 6 months of age. However, the age of diagnosis varies depending on genetic causes: diabetes due to a $6 \mathrm{q} 24$ locus abnormality appears before the age of 1 month in $93 \%$ of cases and before the age of 3 months in $100 \%$ of cases. In $A B C C 8$ and $K C N J 11$ gene mutations, it appears before the age of 1 month in 30\% of cases and between 1 and 6 months in $66 \%$ of cases (4).

At birth, patients have a birth-weight below the 10th percentile in $62 \%$ of cases (4), highlighting the crucial role of insulin secretion in fetal growth. This intrauterine growth retardation is found in all genetic groups with a greater proportion in patients with a $6 \mathrm{q} 24$ abnormality than those carrying a ABCC 8 or KCNJ11 mutation ( 92 vs. $48 \%, p<0.001$ ) (4).

Half of patients with a detectable pancreas by ultrasound experience remission from the diabetes in our cohort (4). This occurs at the age of about 4 months. There is a difference depending on the genetic cause. Patients with a $6 \mathrm{q} 24$ locus abnormality are in remission before the age of 1 year in $97 \%$ of cases (median age 14 weeks) while remission may go as far as the age of 5 years in patients with an ABCC 8 or KCNJ11 mutation (median age 39 weeks) $(4,31)$. Patients with a rare recessive mutation of the INS gene have remission at a median age of 12 weeks (24), whereas the majority of the INS gene mutations are dominant and they never go into remission. The diabetes frequently relapses (in up to $86 \%$ of cases) at the onset of puberty, probably due to the insulin resistance of puberty $(4,32)$. There is no difference between the genetic groups.

Depending on the genetic cause, patients with neonatal diabetes may have other clinical signs associated with diabetes (Table 1).

In neonatal diabetes with normal pancreas morphology, there are associated neurological disorders and developmental defects. Approximately $25 \%$ of patients with a mutation of the $A B C C 8$ or KCNJ11 genes have neurological disorders 
ranging from psychomotor disorders to delayed cognitive development associated with severe epilepsy (DEND syndrome: Developmental delay, Epilepsy, and Neonatal Diabetes) (33). In addition, we have shown that when patients undergo detailed neuro-psychomotor and neuropsychological tests, an attention deficit or language disorder extending as far as dyslexia is found in $100 \%$ of cases (4).

Patients with a 6q24 locus abnormality may have developmental defects (macroglossia, umbilical hernia, cardiac malformations, renal and urinary malformations, non-autoimmune anemia, hypothyroidism with gland in situ) and neurological disorders $(4,11)$.

In neonatal diabetes with abnormal pancreas morphology or with $\beta$ cell destruction, the associated malformations depend on the genetic causes and are often grouped into defined syndromes (Table 1). Figure 2 illustrates a diagnostic strategy by molecular biology.

Recent long-term follow-up data in TNDM support a decrease in maximal insulin secretion capacity to both glucose and arginine stimuli that reflect low insulin mass (34). This study also showed that, regardless of the underlying genetic abnormalities or the duration of diabetes, TNDM was associated with learning difficulties at school. The high relapse rate and absence of identified predictors of relapse in TNDM suggest a need for an HbA1c assay at least every 2 years throughout childhood and for an HbAlc assay and oral glucose tolerance test every year throughout adolescence (34). During childhood, close attention should be directed to education and neurodevelopmental milestones, in TNDM patients with and without diabetes (34).

\section{THERAPEUTIC ASPECTS}

\section{Drug Treatment}

Due to the early onset and associated delayed intrauterine retardation, patients with neonatal diabetes very often receive their initial treatment in a neonatal department. The initial treatment aims to rebalance carbohydrate metabolism. It should be started immediately following diagnosis. The treatment consists of the balance between a calorie and carbohydrate intake necessary to restore normal weight without being excessive to avoid the risk of future insulin resistance $(15-18 \mathrm{~g} / \mathrm{kg} / \mathrm{d}$ carbohydrate) and sufficient insulin-based treatment to achieve the correct metabolic equilibrium. Restricting intake below the nutritional recommendations for children with low birth weight is ineffective given the physiopathology of circulating insulin deficiency.

Insulin-based treatment is difficult to manage due to the very low weight. The therapeutic margins between hypoglycemia and hyperglycemia are small, and both are harmful for neurological development of the newborn. Using an insulin pump with or without dilution of the insulin to $1: 10$ in $0.9 \% \mathrm{NaCl}$ (or with a bona-fide diluent if available) can sometimes improve manageability of the insulin during the first weeks of life $(35,36)$. Blood glucose meters must be able to give a reliable measurement of capillary blood sugar level with the smallest possible quantity of blood (e.g., $0.3 \mu$ l blood). Few "conventional" blood glucose meters meet this criterion. Conventional capillary measurements can be done on the side edge of all the fingers, using auto-lancets offering variable pricking depths. This offers the advantage of sparing newborns' heels. An alternative is to use continuous glucose sensors, either isolated or combined with an insulin pump. In addition to enabling rapid access to interstitial blood glucose (they provide a proxy but do not actually measure the blood glucose value), they can now be coupled to the insulin pump, making it possible to activate the system to stop the insulin pump during hypoglycemia or before it occurs. They also have the advantage of minimizing the number of pricks of the skin. Used under suitable hygiene conditions, there is no increase in skin infections. It is advisable to involve experienced clinicians when treating the child and using these techniques.

Patients with $A B C C 8$ or KCNJ11 mutations are treated successfully using hypoglycemic sulfonylureas, which act by binding to the regulator SUR1 subunit of the potassium channel (37) (Figure 1). The mutated channels remain sensitive to sulfonylureas in $90 \%$ of cases, having an inhibitory effect on the potassium channel of the pancreatic $\beta$ cell and restoring insulin secretion in response to a meal (38). Sulfonylurea therapy appears to be safe and often successful in neonatal diabetes patients before genetic testing results are available (39). An empiric inpatient trial of sulfonylurea can be therefore considered (39). However, obtaining a genetic diagnosis remains imperative to inform long-term management and prognosis.

It has now been demonstrated that treatment with Sulfonylureas provide a better metabolic equilibrium than insulin by normalizing the $\mathrm{HbAlc}$ while strongly reducing the incidence of hypoglycemia in cases of neonatal diabetes with $A B C C 8$ or KCNJ11 mutations. It was also shown recently that hypoglycemic sulphonylureas were able to improve neurological, neuropsychological and visuomotor impairment if they are introduced early in the child's life $(33,40,41)$. Finally, a recent study has shown that it could sometimes be used successfully to replace insulin in neonatal diabetes associated with chromosome 6 methylation abnormalities (42). This emphasizes the importance of making a genetic diagnosis rapidly after diagnosing neonatal diabetes, and especially the early introduction of sulphonylureas. The clinician's aim will be to treat the child with the maximum dose that normalizes blood glucose levels (pre-prandial target: $70-120 \mathrm{mg} / \mathrm{dL}$ - post-prandial target: $100-145 \mathrm{mg} / \mathrm{dL}$ ) without causing hypoglycemia, in order to optimize the drug's effect on the central nervous system. Sulphonylureas are currently only available as a $5 \mathrm{mg}$ tablet and are not licensed for indications in neonatal diabetes. However, glibenclamide has recently obtained the orphan-drug indication from the European Medicine Agency (EMA) in neonatal diabetes. Unlicensed administration is currently achieved by parents through crushing and extemporaneous dilution of the tablets. However, the crushed tablets are poorly soluble in water, which may lead to variations in the dosage actually received by the child. To resolve this problem, a sulphonylurea suspension called Amglidia $^{\mathrm{R}}$ has demonstratable efficacy in this indication (43) and has recently obtained a European Marketing Authorization; it has been available in France under a temporary authorization for use (ATU: Autorisation Temporaire 


\section{Which children to test?}

-Age less than 6 months when diabetes mellitus is detected,

or

- between 6 months and 1 year if extra-pancreatic features :

and/or no evidence of pancreas autoimmunity

and/or multiple autoimmune disorders

or unusual family history

or associated congenital defects

Which tests to perform?

- If less than 6 months of age at diabetes diagnosis (specially if small for gestational age):

search for 6q24 anomalies (Methylation-Specific Multiplex Ligation-Dependent Probe

Amplification (MS-MLPA) +/- microsatellites) and then NGS panel

- If above 6 months of age : NGS panel

FIGURE 2 | Molecular biology approach to neonatal diabetes (44).

d'Utilization) since 2019. It will enable dosages to be adapted more accurately.

An Appendix added to this text describes succinctly the practical aspects of the switch from insulin injection to the glibenclamide suspension licensed in European Union for children and refers to the official summary of product characteristics for detailed information.

\section{Importance of the Genetic Diagnosis}

Genetic analyses enables the diagnosis of monogenic diabetes in nearly $83 \%$ of diabetes diagnosed before the age of 6 months (30). This genetic diagnosis is essential as it will both influence the therapeutic treatment and make it possible to predict potential diabetes-related complications or illnesses. Genetic analyses must be carried out when diagnosing diabetes mellitus in all of the following children: age $<6$ months when diabetes mellitus is detected, or between 6 months and 1 year if extra-pancreatic features and/or no evidence of pancreas autoimmunity and/or multiple autoimmune disorders or unusual family history or associated congenital defects (Figure 2) (44). Testing should not be delayed until other symptoms of the disease appear or potential remission of the disease. It is also of utmost importance to identify if the sulfonylureas can be introduced successfully as high-dose sulfonylurea therapy has been shown to be an appropriate treatment for patients with KCNJ11 permanent neonatal diabetes from diagnosis. This therapy has been shown to be safe and highly effective, maintaining excellent glycemic control for at least 10 years (45).

\section{CONCLUSION}

Neonatal diabetes is a model of rare human genetic disease, important in the understanding of the development and function of the pancreatic $\beta$ cell, and in helping to resolve the pathophysiology of more frequent adult diabetes, such as type 2 diabetes. Neonatal diabetes is often associated with specific neuropsychological or developmental disorders of underlying genetic causes. A multidisciplinary approach is therefore essential. All clinicians called upon to treat a patient with neonatal diabetes should look for these clinical signs. Knowing the natural history and complete phenotype of this disease makes it possible, firstly, to offer patients better treatment and, secondly, to broaden the scope of genetic analyses to genes involved in the development and function of other organs. Long-term follow-up should be implemented, including for the so-called "transient" forms of neonatal diabetes. 


\section{AUTHOR CONTRIBUTIONS}

All authors listed have made a substantial, direct and intellectual contribution to the work, and approved it for publication.

\section{ACKNOWLEDGMENTS}

We were grateful to Prof. Paul Czernichow, Paris, France, for his active participation in our neonatal diabetes project. We thank Mme. Nathalie Pouvreau at the Robert Debré Hospital,

\section{REFERENCES}

1. Iafusco D, Massa O, Pasquino B, Colombo C, Iughetti L, Bizzarri C, et al. Minimal incidence of neonatal/infancy onset diabetes in Italy is 1:90,000 live births. Acta Diabetol. (2012) 49:405-8. doi: 10.1007/s00592-011-0331-8

2. Kanakatti Shankar R, Pihoker C, Dolan LM, Standiford D, Badaru A, Dabelea $\mathrm{D}$, et al. Permanent neonatal diabetes mellitus: prevalence and genetic diagnosis in the SEARCH for diabetes in Youth Study. Pediatr Diabetes. (2013) 14:174-80. doi: 10.1111/pedi.12003

3. Polak M, Cave H. Neonatal diabetes mellitus: a disease linked to multiple mechanisms. Orphanet J Rare Dis. (2007) 2:12. doi: 10.1186/1750-1172-2-12

4. Busiah K, Drunat S, Vaivre-Douret L, Bonnefond A, Simon A, Flechtner I, et al. Neuropsychological dysfunction and neurodevelopmental defects associated with genetic changes in infants with neonatal diabetes mellitus: a prospective cohort study. Lancet Diabetes Endocrinol. (2013) 1:199-207. doi: 10.1016/S2213-8587(13)70059-7

5. Huopio H, Miettinen PJ, Ilonen J, Nykänen P, Veijola R, Keskinen P, et al. Clinical, genetic, and biochemical characteristics of early-onset diabetes in the Finnish population. J Clin Endocrinol Metab. (2016) 101:3018-26. doi: $10.1210 /$ jc.2015-4296

6. Temple IK, Gardner RJ, Robinson DO, Kibirige MS, Ferguson AW, Baum JD, et al. Further evidence for an imprinted gene for neonatal diabetes localised to chromosome 6q22-q23. Hum Mol Genet. (1996) 5:1117-21. doi: $10.1093 / \mathrm{hmg} / 5.8 .1117$

7. Cave H, Polak M, Drunat S, Denamur E, Czernichow P. Refinement of the 6q chromosomal region implicated in transient neonatal diabetes. Diabetes. (2000) 49:108-13. doi: 10.2337/diabetes.49.1.108

8. Gardner RJ, Mackay DJ, Mungall AJ, Polychronakos C, Siebert R, Shield JP, et al. An imprinted locus associated with transient neonatal diabetes mellitus. Hum Mol Genet. (2000) 9:589-96. doi: 10.1093/hmg/9.4.589

9. Arima T, Drewell RA, Arney KL, Inoue J, Makita Y, Hata A, et al. A conserved imprinting control region at the HYMAI/ZAC domain is implicated in transient neonatal diabetes mellitus. Hum Mol Genet. (2001) 10:1475-83. doi: $10.1093 / \mathrm{hmg} / 10.14 .1475$

10. Ma D, Shield JP, Dean W, Leclerc I, Knauf C, Burcelin RR, et al. Impaired glucose homeostasis in transgenic mice expressing the human transient neonatal diabetes mellitus locus, TNDM. J Clin Invest. (2004) 114:339-48. doi: 10.1172/JCI200419876

11. Docherty LE, Kabwama S, Lehmann A, Hawke E, Harrison L, Flanagan SE, et al. Clinical presentation of 6q24 transient neonatal diabetes mellitus (6q24 TNDM) and genotype-phenotype correlation in an international cohort of patients. Diabetologia. (2013) 56:758-62. doi: 10.1007/s00125-013-2832-1

12. Mackay DJ, Callaway JL, Marks SM, White HE, Acerini CL, Boonen SE, et al. Hypomethylation of multiple imprinted loci in individuals with transient neonatal diabetes is associated with mutations in ZFP57. Nat Genet. (2008) 40:949-51. doi: 10.1038/ng.187

13. Clement JP, Kunjilwar K, Gonzalez G, Schwanstecher M, Panten U, AguilarBryan L, et al. Association and stoichiometry of KATP channel subunits. Neuron. (1997) 18:827-38. doi: 10.1016/S0896-6273(00)80321-9

14. Ashcroft FM, Gribble FM. Correlating structure and function in ATP-sensitive $\mathrm{K}^{+}$channels. Trends Neurosci. (1998) 21:288-94. doi: 10.1016/S0166-2236(98)01225-9
Paris, for the biological diagnosis and the support of the bank. We also thank all clinicians in France and abroad, as well as the children and their families, who trust us in this field.

\section{SUPPLEMENTARY MATERIAL}

The Supplementary Material for this article can be found online at: https://www.frontiersin.org/articles/10.3389/fped. 2020.540718/full\#supplementary-material
15. Gloyn AL, Pearson ER, Antcliff JF, Proks P, Bruining GJ, Slingerland AS, et al. Activating mutations in the gene encoding the ATP-sensitive potassiumchannel subunit Kir6.2 and permanent neonatal diabetes. N Engl J Med. (2004) 350:1838-49. doi: 10.1056/NEJMoa032922

16. Vaxillaire M, Populaire C, Busiah K, Cave H, Gloyn AL, Hattersley AT, et al. Kir6.2 mutations are a common cause of permanent neonatal diabetes in a large cohort of French patients. Diabetes. (2004) 53:2719-22. doi: 10.2337/diabetes.53.10.2719

17. Babenko AP, Polak M, Cave H, Busiah K, Czernichow P, Scharfmann R, et al. Activating mutations in the ABCC8 gene in neonatal diabetes mellitus. N Engl J Med. (2006) 355:456-66. doi: 10.1056/NEJMoa055068

18. Stoy J, Edghill EL, Flanagan SE, Ye H, Paz VP, Pluzhnikov A, et al. Insulin gene mutations as a cause of permanent neonatal diabetes. Proc Natl Acad Sci USA. (2007) 104:15040-4. doi: 10.1073/pnas.0707291104

19. Polak M, Dechaume A, Cave H, Nimri R, Crosnier H, Sulmont V, et al. Heterozygous missense mutations in the insulin gene are linked to permanent diabetes appearing in the neonatal period or in early-infancy: a report from the French ND study group. Diabetes. (2008) 57:1115-9. doi: 10.2337/db07-1358

20. Izumi T, Yokota-Hashimoto H, Zhao S, Wang J, Halban PA, Takeuchi T. Dominant negative pathogenesis by mutant proinsulin in the Akita diabetic mouse. Diabetes. (2003) 52:409-16. doi: 10.2337/diabetes.52.2.409

21. Colombo C, Porzio O, Liu M, Massa O, Vasta M, Salardi S, et al. Seven mutations in the human insulin gene linked to permanent neonatal/infancy-onset diabetes mellitus. J Clin Invest. (2008) 118:2148-56. doi: 10.1172/JCI33777

22. Meur G, Simon A, Harun N, Virally M, Dechaume A, Bonnefond A, et al. Insulin gene mutations resulting in early-onset diabetes: marked differences in clinical presentation, metabolic status, and pathogenic effect through endoplasmic reticulum retention. Diabetes. (2010) 59:653-61. doi: $10.2337 / \mathrm{db} 09-1091$

23. Balboa D, Saarimäki-Vire J, Borshagovski D, Survila M, Lindholm P, Galli E, et al. Insulin mutations impair beta-cell development in a patient-derived iPSC model of neonatal diabetes. Elife. (2018) 7:e38519. doi: 10.7554/eLife.38519

24. Garin I, Edghill EL, Akerman I, Rubio-Cabezas O, Rica I, Locke JM, et al. Recessive mutations in the INS gene result in neonatal diabetes through reduced insulin biosynthesis. Proc Natl Acad Sci USA. (2010) 107:3105-10 doi: 10.1073/pnas.0910533107

25. Bonnefond A, Lomberk G, Buttar N, Busiah K, Vaillant E, Lobbens S, et al. Disruption of a novel Kruppel-like transcription factor p300-regulated pathway for insulin biosynthesis revealed by studies of the c.-331 INS mutation found in neonatal diabetes mellitus. J Biol Chem. (2011) 286:2841424. doi: 10.1074/jbc.M110.215822

26. Stoffel M, Froguel P, Takeda J, Zouali H, Vionnet N, Nishi S, et al. Human glucokinase gene: isolation, characterization, and identification of two missense mutations linked to early-onset non-insulin-dependent (type 2) diabetes mellitus. Proc Natl Acad Sci USA. (1992) 89:7698. doi: $10.1073 /$ pnas.89.16.7698

27. Njolstad PR, Sovik O, Cuesta-Munoz A, Bjorkhaug L, Massa O, Barbetti F, et al. Neonatal diabetes mellitus due to complete glucokinase deficiency. $N$ Engl J Med. (2001) 344:1588-92. doi: 10.1056/NEJM200105243 442104 
28. Gloyn AL, Ellard S, Shield JP, Temple IK, Mackay DJ, Polak M, et al. Complete glucokinase deficiency is not a common cause of permanent neonatal diabetes. Diabetologia. (2002) 45:290. doi: 10.1007/s00125-001-0746-9

29. Vaxillaire M, Samson C, Cave H, Metz C, Froguel P, Polak M. Glucokinase gene mutations are not a common cause of permanent neonatal diabetes in France. Diabetologia. (2002) 45:454-5. doi: 10.1007/s00125-001-0741-1

30. Johnson MB, De Franco E, Greeley SAW, Letourneau LR, Gillespie KM; International DS-PNDM Consortium, Wakeling MN, et al. Trisomy 21 is a cause of permanent neonatal diabetes that is autoimmune but not HLA associated. Diabetes. (2019) 68:1528-35. doi: 10.2337/db19-0045

31. Gloyn AL, Reimann F, Girard C, Edghill EL, Proks P, Pearson ER, et al. Relapsing diabetes can result from moderately activating mutations in KCNJ11. Hum Mol Genet. (2005) 14:925-34. doi: 10.1093/hmg/ddi086

32. Amiel SA, Caprio S, Sherwin RS, Plewe G, Haymond MW, Tamborlane WV. Insulin resistance of puberty: a defect restricted to peripheral glucose metabolism. J Clin Endocrinol Metab. (1991) 72:277-82. doi: 10.1210/jcem-72-2-277

33. Slingerland AS, Hurkx W, Noordam K, Flanagan SE, Jukema JW, Meiners LC, et al. Sulphonylurea therapy improves cognition in a patient with the V59M KCNJ11 mutation. Diabet Med. (2008) 25:277-81. doi: 10.1111/j.1464-5491.2007.02373.x

34. Le Bourgeois F, Beltrand J, Baz B, Julla JB, Riveline JP, Simon A, et al. TNDM long-term follow-up study group long-term metabolic and socioeducational outcomes of transient neonatal diabetes: a longitudinal and cross-sectional study. Diabetes Care. (2020) 43:1191-9. doi: 10.2337/dc19-0324

35. Rabbone I, Barbetti F, Marigliano M, Bonfanti R, Piccinno E, Ortolani F, et al. Successful treatment of young infants presenting neonatal diabetes mellitus with continuous subcutaneous insulin infusion before genetic diagnosis. Acta Diabetol. (2016) 53:559-65. doi: 10.1007/s00592-015-0828-7

36. Tubiana-Rufi N. Insulin pump thapy in noenatal diabetes. Endocr Dev. (2007) 12:67-74. doi: 10.1159/000109606

37. Pearson ER, Flechtner I, Njolstad PR, Malecki MT, Flanagan SE, Larkin $\mathrm{B}$, et al. Switching from insulin to oral sulfonylureas in patients with diabetes due to Kir6.2 mutations. N Engl J Med. (2006) 355:467-77. doi: 10.1056/NEJMoa061759

38. Garcin L, Mericq V, Fauret-Amsellem AL, Cave H, Polak M, Beltrand J. Neonatal diabetes due to potassium channel mutation: response to sulfonylurea according to the genotype. Pediatr Diabetes. (2020) 21:932-41. doi: $10.1111 /$ pedi.13041

39. Carmody D, Bell CD, Hwang JL, Dickens JT, Sima DI, Felipe DL, et al. Sulfonylurea treatment before genetic testing in neonatal diabetes: pros and cons. J Clin Endocrinol Metab. (2014) 99:2709-14. doi: 10.1210/jc.2014-2494
40. Slingerland AS, Nuboer R, Hadders-Algra M, Hattersley AT, Bruining GJ. Improved motor development and good long-term glycaemic control with sulfonylurea treatment in a patient with the syndrome of intermediate developmental delay, early-onset generalised epilepsy and neonatal diabetes associated with the V59M mutation in the KCNJ11 gene. Diabetologia. (2006) 49:2559-63. doi: 10.1007/s00125-006-0407-0

41. Shah RP, Spruyt K, Kragie BC, Greeley SAW, Msall ME. Visuomotor performance in KCNJ11-related neonatal diabetes is impaired in children with DEND-associated mutations and may be improved by early treatment with sulfonylureas. Diabetes Care. (2012) 35:2086-8. doi: $10.2337 / \mathrm{dc} 1$ $1-2225$

42. Garcin L, Kariyawasam D, Busiah K, Fauret-Amsellem A-L, Le Bourgeois F, Vaivre-Douret L, et al. Successful off-label sulfonylurea treatment of neonatal diabetes mellitus due to chromosome 6 abnormalities. Pediatr Diabetes. (2018) 19:663-9. doi: 10.1111/pedi.12635

43. Beltrand J, Baptiste A, Busiah K, Bouazza N, Godot C, Boucheron A, et al. Glibenclamide oral suspension: suitable and effective in patients with neonatal diabetes. Pediatr Diabetes. (2019) 20:246-54. doi: 10.1111/pedi. 12823

44. Hattersley AT, Greeley SAW, Polak M, Rubio-Cabezas O, Njølstad PR, Mlynarski W, et al. ISPAD clinical practice consensus guidelines 2018: the diagnosis and management of monogenic diabetes in children and adolescents. Pediatr Diabetes. (2018) 19:47-63. doi: 10.1111/pedi.12772

45. Bowman P, Sulen Å, Barbetti F, Beltrand J, Svalastoga P, Codner E, et al. Effectiveness and safety of long-term treatment with sulfonylureas in patients with neonatal diabetes due to KCNJ11 mutations: an international cohort study. Lancet Diabetes Endocrinol. (2018) 6:637-46. doi: 10.1016/S2213-8587(18)30106-2

Conflict of Interest: MP is a scientific advisor for AMMTEK.

The remaining authors declare that the research was conducted in the absence of any commercial or financial relationships that could be construed as a potential conflict of interest.

Copyright (C) 2020 Beltrand, Busiah, Vaivre-Douret, Fauret, Berdugo, Cavé and Polak. This is an open-access article distributed under the terms of the Creative Commons Attribution License (CC BY). The use, distribution or reproduction in other forums is permitted, provided the original author(s) and the copyright owner(s) are credited and that the original publication in this journal is cited, in accordance with accepted academic practice. No use, distribution or reproduction is permitted which does not comply with these terms. 